\title{
Bifidobacterium bifidum BF-1 suppresses Helicobacter pylori-induced genes in human epithelial cells
}

\author{
Y. Shirasawa, ${ }^{1}$ H. Shibahara-Sone, T. lino, and F. Ishikawa \\ Yakult Central Institute for Microbiological Research, Kunitachi, Tokyo, 186-8650, Japan
}

\begin{abstract}
Helicobacter pylori infection alters gene expression in host cells. Specifically, inflammatory chemokines such as IL-8 are upregulated in the gastric mucosa during H. pylori infection. Although the mechanism by which H. pylori causes inflammation of the gastric mucosa is not yet understood, many studies have suggested that nuclear factor kappa B (NF- $\kappa \mathrm{B})$ plays a key regulatory role in host cells. We have shown that preincubation with Bifidobacterium bifidum strain BF-1, a probiotic strain known to improve H. pylori-associated gastritis, suppresses induction of IL- 8 by the pathogen. To investigate how how BF-1 affects gene expression in $H$. pylori-infected cells, we performed microarray analysis to assess gene expression in epithelial cells, which had been preincubated with BF-1 and infected with $H$. pylori. We found that preincubation with BF-1 suppresses the expression of H. pylori-induced genes in human cells and that most of the affected genes are related to the NF- $\kappa \mathrm{B}$ signaling pathways. These results suggest that BF-1 can affect the regulatory mechanism of the NF$\kappa \mathrm{B}$ signaling pathways.
\end{abstract}

Key words: Bifidobacterium bifidum, Helicobacter pylori, probiotics

\section{INTRODUCTION}

Chronic Helicobacter pylori infection of the gastric mucosa affects approximately half of the world's population, leads to chronic gastritis and peptic ulcer disease, and is linked to gastric carcinoma (Morris and Nicholson, 1987; Uemura et al., 1997). The oral administration of 3 or 4 antibiotics and a proton pump inhibitor is currently recommended to eradicate $H$. pylori; however, increasing antimicrobial resistance has diminished the efficacy of standard eradication regimens (Selgrad et al., 2009). A combination therapy, including both antibiotics and probiotics, is proposed as an alternative to standard eradication therapy. For patients who are

Received March 19, 2010.

Accepted June 11, 2010.

${ }^{1}$ Corresponding author: yukio-shirasawa@yakult.co.jp infected with $H$. pylori but remain asymptomatic, the risk of therapeutic failure and adverse events associated with standard antibiotic therapy may make coexistence with the pathogen the preferred option, particularly if the pathogenic effects of $H$. pylori can be suppressed by probiotics.

Probiotics are defined as live microorganisms that confer a health benefit on the host; they are considered a useful alternative to avoid overuse of antibiotics. Thus far, most studies on probiotics have focused on the intestinal flora, but studies of probiotic effects on other organs have begun to appear, particularly in the field of gastric diseases. Several evaluation trials of probiotic therapies on $H$. pylori-infected humans have been performed (Sakamoto et al., 2001; Wang et al., 2004; Lesbros-Pantoflickova et al., 2007; Boonyaritichaikij et al., 2009; Worona-Dibner, 2009). Multi-species probiotic preparations have been shown to have beneficial effects against H. pylori infections (Myllyluoma et al., 2008). Pretreatment with Lactobacillus- and Bifidobacteriumcontaining yogurt improved the efficacy of quadruple antibiotic therapy in eradicating residual $H$. pylori infection after failed triple therapy (Sheu et al., 2006). Systematic reviews and meta-analyses have shown that fermented milk-based probiotic preparations improve H. pylori eradication rates by 5 to $15 \%$ (Sachdeva and Nagpal, 2009).

Along with lactic acid bacteria, Bifidobacteria are used in the production of yogurt and are known to have probiotic effects (Shimakawa et al., 2003; Picard et al., 2005). Bifidobacteria are known to adhere to epithelial cells (Bernet et al., 1993; Gueimonde et al., 2005; Guglielmetti et al., 2008). The anti-ulcer effects of Bifidobacterium bifidum YIT 4007 have been shown using acetic acid-induced gastric ulcer and ethanolinduced erosion models in rats (Nagaoka et al., 1994). The administration of B. bifidum dry powder has been successfully used to treat $H$. pylori-positive gastric ulcer patients; in 3 out of 10 cases, $H$. pylori was successfully eradicated from the gastric mucous membrane (Nagaoka et al., 2003). Bifidobacterium bifidum BF-1 (BF-1) was isolated from B. bifidum YIT 4007 as an oxygen-resistant strain; a randomized, double-blind, placebo-controlled comparative study has shown that 
consumption of BF-1-fermented milk improved $H$. pylori-induced gastric symptoms. It was also shown that H. pylori-induced IL-8 secretion was suppressed by preincubation of a human gastric carcinoma cell line, GCIY, with BF-1 (Miki et al., 2007). The inflammatory cytokine IL-8 is induced by $H$. pylori infection, and is known to be specifically involved in the recruitment and activation of neutrophils, thus playing an important role in the gastric inflammation that accompanies neutrophil infiltration (Crabtree et al., 1994). In addition to IL-8, many other inflammatory cytokines and cellular adhesive factors seem to be involved in gastric inflammation (Yamaoka et al., 1998). It is believed that nuclear factor- $\kappa \mathrm{B}(\mathbf{N F}-\boldsymbol{\kappa} \mathbf{B})$ plays a key role in the regulation of these genes (Sharma et al., 1998). The mechanism by which $H$. pylori causes inflammation is not yet understood, but many reports have shown that various inflammatory responses in the gastric mucosa are mediated by NF- $\kappa \mathrm{B}$ (Maeda et al., 2001).

In this study, we analyzed the suppression mechanism of BF-1 by investigating the whole gene expression profile of BF-1 pretreated and $H$. pylori-infected cells using a 2-color microarray method. Quantitative analyses were performed using real-time PCR to confirm the microarray results.

\section{MATERIALS AND METHODS}

\section{Bacterial Culture}

Helicobacter pylori YIT 10238 (ATCC 43504), YIT 11123 (ATCC 700392), and YIT 10057 (clinical isolate) strains were obtained from the culture collection of Yakult Central Institute of Microbiological Research (Tokyo, Japan) and cultured in Brucella broth (Becton Dickinson Co., Sparks, MD) with $10 \%$ heat-inactivated horse serum under microaerobic conditions using AnaeroPack Helico (Mitsubishi Gas Chemical Co. Inc., Tokyo, Japan) with mild shaking (140 rpm) at $37^{\circ} \mathrm{C}$ for 48 h. Bifidobacterium bifidum BF-1 was cultured in modified International Lactobacilli Shirota (mILS) broth (Shimakawa et al., 2003) under anaerobic conditions using AnaeroPack (Mitsubishi Gas Chemical Co. Inc.).

\section{Cell Culture}

Cells from a human gastric epithelial cell line GCIY (RCB0555; Nozue et al., 1991) were obtained from Riken Cell Bank (Tokyo, Japan) and cultured in Eagle's minimal essential medium (MEM; Nissui, Osaka, Japan) containing $15 \%$ fetal bovine serum (Gibco, Invitrogen, Carlsbad, CA) with $100 \mathrm{U} / \mathrm{mL}$ of penicillin $\mathrm{G}$ and 100 $\mu \mathrm{g} / \mathrm{mL}$ of streptomycin sulfate at $37^{\circ} \mathrm{C}$ in humidified air containing $5 \% \mathrm{CO}_{2}$.

\section{Infection Procedures}

Helicobacter pylori YIT 10238 and BF-1 were cultured as described above, washed, and resuspended in MEM without antibiotics. Helicobacter pylori infection studies were performed with GCIY cells in vitro. The GCIY cells, which were maintained in MEM supplemented with $15 \%$ fetal serum, were seeded into collagen-coated, 6 -well tissue culture plates and grown to confluence at $37^{\circ} \mathrm{C}$. Then, BF-1 at a concentration of $10^{9} \mathrm{cfu} / \mathrm{mL}$ or control medium was added to the tissue culture plates and co-incubated with GCIY cells. After $3 \mathrm{~h}$ of incubation, cells were washed 3 times with medium; then, $H$. pylori at $10^{7} \mathrm{cfu} / \mathrm{mL}$ or control medium was added to the cells and incubated for 4 or $6 \mathrm{~h}$.

\section{RNA Extraction}

Infected cells were washed 3 times with MEM and treated with RNAlater (Qiagen, Düsseldorf, Germany) for $16 \mathrm{~h}$ to stabilize RNA. After removing the RNAlater, total RNA was extracted using the RNeasy Mini kit (Qiagen). Quality of RNA was evaluated with the Agilent 2100 BioAnalyzer (Agilent Technologies, Santa Clara, CA) and RNA yield was determined spectrophotometrically.

\section{Microarray Procedures and Data Analysis}

A whole human genome oligo DNA microarray kit $4 \mathrm{x} 44 \mathrm{k}$ (Agilent Technologies), which contains 4 independent microarrays on one slide, and 60-mer oligo probe sets were used to monitor the expression of more than 41,000 human transcripts per microarray. Total RNA was reverse-transcribed and labeled using the Agilent Low RNA Input Linear Amplification Kit PLUS, TwoColor to produce cyanine $3(\mathbf{C y 3})$ - or cyanine $5(\mathbf{C y 5})$ labeled cRNA. The cRNA were purified with RNeasy columns and quantified. The sample was fragmented and suspended in Hybridization Buffer HI-PRM (Agilent) before application to the microarray for hybridization. The microarray was incubated for $17 \mathrm{~h}$ at $65^{\circ} \mathrm{C}$ with $10 \mathrm{rpm}$ rotation in a hybridization chamber. After hybridization, the microarray was washed with $37^{\circ} \mathrm{C}$ prewarmed Gene Expression Wash Buffer (Agilent), acetonitrile (Sigma-Aldrich Co., St. Louis, MO), and Stabilization and Drying solution (Agilent). Once dry, the microarray was scanned using the Agilent 2505B scanner, and image processing was performed using the Feature Extraction V9.5 software (Agilent). Data were analyzed by GeneSpring GX7.3 software (Agilent). A first set of microarrays was used for an experiment with a 4-h H. pylori incubation. A second set was used for a dye exchange experiment to eliminate dye bias effects 
with a 4-h $H$. pylori incubation. A third set was used for an experiment with a 6 -h $H$. pylori incubation.

\section{IL-8 Assay by ELISA}

The GCIY cells were cultured in a 96-well plate as described above. The indicated concentrations of BF-1 or medium were added to the cells and incubated for 3 $\mathrm{h}$. Then, the sheet of cells was rinsed 3 times with fresh medium and incubated with $H$. pylori at $10^{7} \mathrm{cfu} / \mathrm{mL}$ or control medium for $20 \mathrm{~h}$. Clarified culture supernatants were analyzed for IL-8 protein with Immunoassay Kit Human IL-8/NAP1 (Biosource, Invitrogen) as directed by the manufacturer. Data are the means \pm standard deviations of the means $(\mathrm{n}=3)$.

\section{Real-Time PCR}

Primers for PCR were designed with Primer Express software (Applied Biosystems Inc., Foster City, CA) according to the transcription sequence data of each gene obtained from Ensembl (http://www.ensembl. org/index.html). The following were used as the PCR primers: IL-8 forward, 5'-CACCGGAAGGAACCATCTCA-3', and IL-8 reverse, 5'-AGAGCCACGGCCAGCTT-3'; NF- $\kappa$ B forward, 5'-AAATCTAATGCTGGGATGAAGCA-3', and NF- $\kappa \mathrm{B}$ reverse, 5'-CACAACCTTCAGGGTCCTTTTT-3'; myeloid differentiation primary response gene (88) (MyD88) forward, 5'-GAGCTGGCGGGCATCAC-3', and MyD88 reverse, 5'-TCGAAACGCTCAGGCATATG-3'; GAPDH forward, 5'-ATGGAAATCCCATCACCATCTT-3', and GAPDH reverse, 5'-CGCCCCACTTGATTTTGG-3'.

Total RNA was reverse-transcribed using the PrimeScript RT reagent Kit (Takara Bio Inc., Shiga, Japan), and $10 \mathrm{ng}$ of cDNA per reaction was labeled by using Power SYBR Green PCR Master Mix (Applied Biosystems) according to the manufacturer's instructions. Quantitative analyses were performed using real-time PCR on a 7900HT Fast Real-Time PCR System (Applied Biosystems). Results of the different RNA samples were normalized for RNA quantity using the housekeeping gene GAPDH.

\section{Statistical Analysis and Microarray Data Deposition}

Statistical differences were analyzed by paired Student's $t$-test. The entire collection of microarray data from this study were deposited in the Gene Expression Omnibus (GEO; http://www.ncbi.nlm.nih.gov/ projects/geo/; accession no.: GSE20171).

\section{RESULTS}

\section{H. pylori Induction and BF-1 Suppression of IL-8 in Epithelial Cells}

Secretion of IL-8 from GCIY cells was quantified by ELISA. Figure 1 shows that preincubation with BF-1 suppresses IL-8 induction in a dose-dependent manner. In the presence of BF- 1 at $10^{9} \mathrm{cfu} / \mathrm{mL}$, IL- 8 production induced by $H$. pylori strains YIT 10238, YIT 11123, and YIT 10057 was suppressed by 40, 46, and 33\%, respectively $(P<0.001)$, confirming the results of previous experiments performed with YIT 10238 (Miki et al., 2007).

\section{Microarray Analyses}

Microarray analyses were performed to establish whole gene expression profiles of human gastric GCIY cells with and without BF-1 preincubation and H. pylori YIT 10238 infection. A slide set contains 4 independent microarrays, and the 2-color method was employed to compare the different conditions. Table 1 shows the combination of samples in each array.

In microarray 1 of the first set, the gene expression in the control cells [pretreated and incubated with medium $(\mathrm{Cy} 3)$ ] versus the infected cells [pretreated with medium (Cy5)] were compared. Of all human genes, 838 genes were shown to be upregulated more than 2.0-fold in the presence of $H$. pylori infection. We have excluded unannotated genes from the list and categorized them by function. We found that many known inflammatory genes were activated as expected, and several gene clusters of inflammatory genes could serve as signatures for H. pylori infection, including genes encoding chemokines, chemokine receptors, fibroblast growth factor, interleukins, tumor necrosis factor (TNF) superfamily proteins, matrix metallopeptidases, and cell adhesion molecules (Table 2). As expected, IL-8 was strongly activated.

In microarray 2, gene expression profiles from BF-1 pretreated, noninfected cells $(\mathrm{Cy} 3)$ and $\mathrm{BF}-1$ pretreated, H. pylori-infected cells (Cy5) were compared. The genes induced by $H$. pylori in array 1 were also upregulated in array 2; however, we found that the extent of upregulation was reduced for most of the H. pyloriinduced genes listed in Table 2. The expression of IL-8 was suppressed drastically. These results suggest that $\mathrm{BF}-1$ preincubation is responsible for the suppression of $H$. pylori-induced gene expression. These characteristic gene signatures were confirmed and selected as described in the following section. 


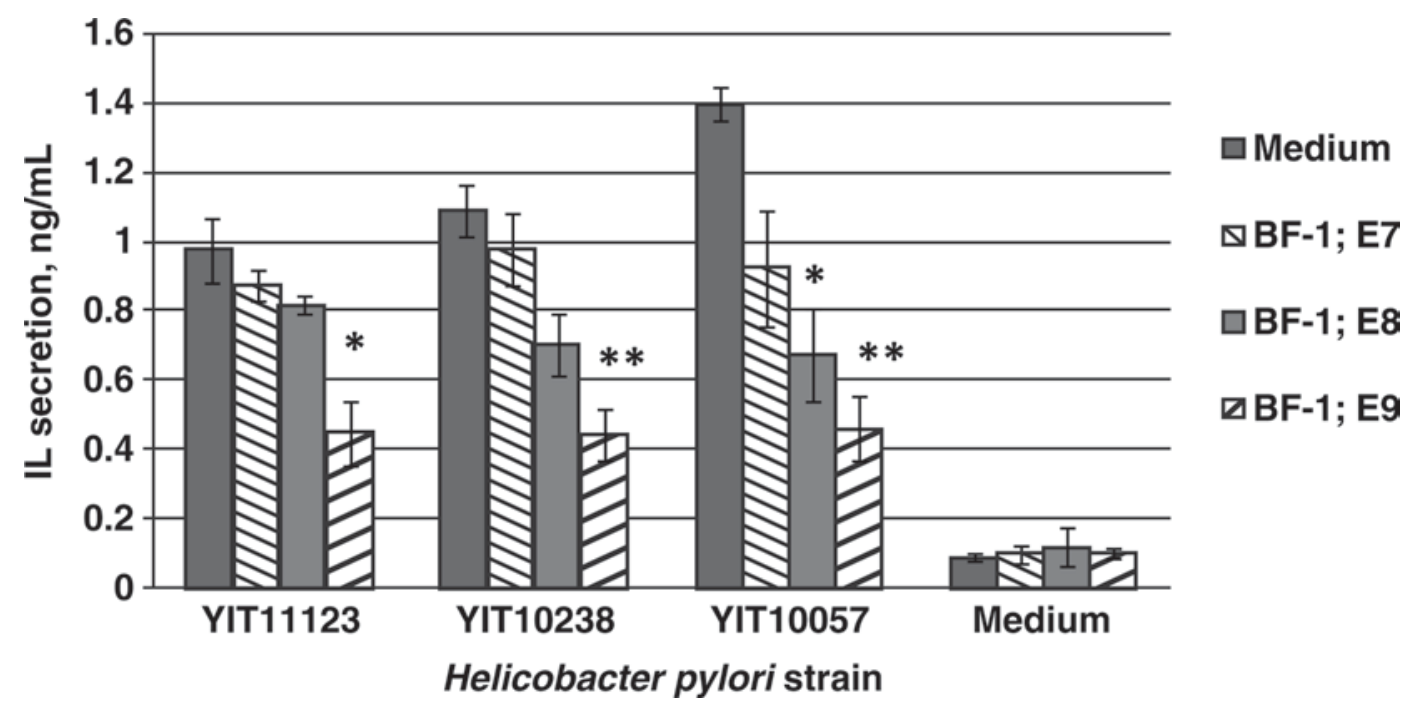

Figure 1. Effect of Bifidobacterium bifidum BF-1 on IL-8 secretion (ng/mL) of human gastric carcinoma (GCIY) cells. After preincubation of BF-1 at $10^{7}(\mathrm{E} 7), 10^{8}(\mathrm{E} 8)$, and $10^{9}(\mathrm{E} 9) \mathrm{cfu} / \mathrm{mL}$ or medium, Helicobacter pylori at $10^{7} \mathrm{cfu} / \mathrm{mL}$ or medium was added. The amount of secreted IL- 8 was assayed by ELISA. Data are the means \pm standard deviations of the means $(\mathrm{n}=3)$. $* P<0.001$ and $* * P<0.0001$ compared with the results for preincubation with medium.

To confirm and further characterize the effect of BF-1, microarray 3 compared gene expression profiles in 2 sets of $H$. pylori-infected cells, only one of which was pretreated with BF-1 (Cy5). The suppression of upregulated genes appeared as downregulated genes in this array; these results supported the results of microarray 2.

Microarray 4 demonstrated that preincubation with BF-1 does not significantly ( $>2$ fold) affect the expression of inflammatory genes (Cy5). Expression of IL-8 was not detected in these cells.

The second slide set was used for a dye-exchange experiment after $4 \mathrm{~h}$ of $H$. pylori infection. The results were the mirror image of the first set, and no dye bias was observed, lending support to the validity of the results from the first set of slide. The third slide set was used to characterize samples after $6 \mathrm{~h}$ of $H$. pylori infection. Some differences in the degree of activation or inactivation were observed, most likely because of the difference in incubation time; however, the overall patterns of gene expression were the same (data are available from GEO).

\section{Selection of Genes with Expression Profiles Matching IL-8}

In each of the 4 microarrays, IL- 8 exhibited a characteristic profile; the gene was induced by $H$. pylori and suppressed by BF-1 and was not activated in the presence of BF-1 alone. A group of genes exhibiting a profile similar to that of IL- 8 throughout the $4 \mathrm{mi}$ croarrays was selected using the GeneSpring GX7.3 software (Agilent). Typical patterns of those genes are depicted in Figure 2, which include the data of slide 2. The selected genes and their normalized intensities are listed in Table 3; these include chemokines, cytokines, TNF superfamily proteins, and adhesion molecules, all of which are consistent with those listed in Table 2. The list of these overlapping genes and the ratio of normalized expression of array 1 and array 2 are shown in Table 4 . These results suggest that BF-1 can suppress many types of inflammatory processes as well as IL-8. It is also clear that most of these genes are known to be regulated by $\mathrm{NF}-\kappa \mathrm{B}$ or are involved in the NF- $\kappa \mathrm{B}$ network. This strong positive correlation

Table 1. Sample labeling combination of microarrays

\begin{tabular}{|c|c|c|c|c|}
\hline \multirow[b]{2}{*}{ Microarray } & \multicolumn{2}{|l|}{ Cyanine 3} & \multicolumn{2}{|c|}{ Cyanine 5} \\
\hline & Pretreatment & Treatment & Pretreatment & Treatment \\
\hline 1 & Medium & Medium & Medium & Helicobacter pylori \\
\hline 2 & Bifidobacterium bifidum BF-1 & Medium & B. bifidum BF-1 & H. pylori \\
\hline 3 & Medium & H. pylori & B. bifidum BF-1 & H. pylori \\
\hline 4 & Medium & Medium & B. bifidum BF-1 & Medium \\
\hline
\end{tabular}


between BF-1-suppressed genes and NF- $\kappa$ B-regulated genes may suggest that BF-1 affects the regulation of NF- $\kappa$ B pathways.

\section{Real-Time PCR}

The IL-8 microarray expression data were confirmed by quantitative real-time PCR. Figure 3a shows the relative expression of the gene: IL-8 was upregulated more than 49 -fold at $4 \mathrm{~h}$ after $H$. pylori infection. With BF-1 preincubation, upregulation was reduced by $33 \%$ $(P=0.04)$.

Because the up- and downregulation of NF- $\kappa$ B-related genes was not quantifiable by microarray analysis, the expression levels of NF- $\kappa \mathrm{B}$ and MyD88 were also quantified by real-time PCR (Figure 3b). Expression of NF- $\kappa$ B increased 2-fold by $H$. pylori and this increase was suppressed $87 \%$ by BF-1 preincubation (results statistically insignificant). Expression of MyD88 was not upregulated by $H$. pylori infection but was suppressed $59 \%(P=0.03)$ by BF-1 preincubation.

\section{DISCUSSION}

Bifidobacterium bifidum BF-1 has been shown to be effective in improving $H$. pylori-infected gastric symptoms. To understand the mechanism by which BF-1 mediates its beneficial effects, we investigated gene

Table 2. Differentially expressed genes in Helicobacter pylori-infected cells in microarray 1

\begin{tabular}{|c|c|c|}
\hline Gene name ${ }^{1}$ & $\begin{array}{l}\text { Normalized } \\
\text { expression }\end{array}$ & $\begin{array}{l}\text { GenBank } \\
\text { accession no. }\end{array}$ \\
\hline \multicolumn{3}{|l|}{ Adhesion molecules } \\
\hline VCAM-1 & 7.0 & NM_001078 \\
\hline ICAM-1 & 14.1 & NM_000201 \\
\hline Laminin, $\alpha 3$ (LAMA3) & 5.8 & NM_198129 \\
\hline Laminin, $\gamma 2$ (LAMC2) & 2.3 & NM_005562 \\
\hline OLR1 & 6.0 & NM_002543 \\
\hline \multicolumn{3}{|l|}{ Chemokines and chemokine receptors } \\
\hline CCL2 & 15.6 & NM_002982 \\
\hline CCL5/RANTES & 8.2 & NM_002985 \\
\hline CCL20/LARC & 26.1 & NM_004591 \\
\hline CXCL1/Gro- $\alpha$ & 13.9 & NM_001511 \\
\hline CXCL2/Gro- $\beta$ & 6.8 & NM_002089 \\
\hline CXCL3/Gro- $\gamma$ & 16.4 & NM_002090 \\
\hline CXCL5/ENA-78 & 4.0 & NM_002994 \\
\hline CXCL10 & 6.0 & NM_001565 \\
\hline CX3CL1 & 3.4 & NM_002996 \\
\hline CXCR4/fusin & 8.0 & NM_001008540 \\
\hline \multicolumn{3}{|l|}{ Interleukins } \\
\hline IL-8 & 80.0 & NM_000584 \\
\hline IL-23A & 2.9 & NM_016584 \\
\hline \multicolumn{3}{|l|}{ Growth factor and receptors } \\
\hline Fibroblast growth factor (FGF) 18 & 14.8 & NM_003862 \\
\hline \multicolumn{3}{|c|}{ Tumor necrosis factor (TNF) superfamily and receptors } \\
\hline LTB & 8.3 & NM_002341 \\
\hline TNF- $\alpha$ & 28.6 & NM_000594 \\
\hline TNFAIP2 & 7.1 & NM_006291 \\
\hline TNFAIP3 & 6.3 & NM_006290 \\
\hline TNFAIP6 & 2.0 & NM_007115 \\
\hline TNFRSF9 & 3.3 & NM_001561 \\
\hline TNFRSF1B & 2.1 & NM_001066 \\
\hline TNFRSF10B & 2.8 & NM_003842 \\
\hline TRAF1 & 5.5 & NM_005658 \\
\hline \multicolumn{3}{|l|}{ Others } \\
\hline ITGB8 & 2.2 & BC042028 \\
\hline Metalloproteinase 1 (MMP1) & 2.8 & NM_002421 \\
\hline Metalloproteinase 7 (MMP7) & 2.9 & NM_002423 \\
\hline Metalloproteinase 9 (MMP9) & 4.1 & NM_004994 \\
\hline NFKBIA & 6.0 & NM_020529 \\
\hline \multicolumn{3}{|c|}{$\begin{array}{l}{ }^{1} \text { VCAM-1 = vascular cell adhesion molecule-1; ICAM-1 = intercellular adhesion molecule-1; OLR1 = oxidized } \\
\text { low-density lipoprotein receptor } 1 \text {; CCL = chemokine ligands; CXCR = chemokine receptor; RANTES }=\text { regu- } \\
\text { lated upon activation, normal T cell expressed and secreted; LARC = liver activation regulated chemokine } \\
\text { Gro = growth-regulated protein; ENA-78 = epithelial cell-derived neutrophil-activating peptide } 78 ; \text { LTB }= \\
\text { leukotriene B; TNFAIP = TNF- } \alpha \text {-induced protein; TNFRSF = TNF receptor superfamily; TRAF = TNF } \\
\text { receptor-associated factor; ITGB }=\text { integrin beta-8; NFKBIA = nuclear factor of kappa light polypeptide gene } \\
\text { enhancer in B-cells inhibitor, alpha. }\end{array}$} \\
\hline
\end{tabular}


Table 3. Normalized intensity (log scale) of the genes in each microarray (1 to 4 )

\begin{tabular}{|c|c|c|c|c|c|c|c|c|}
\hline Gene name $^{1}$ & \multicolumn{4}{|c|}{ Slide 1 (green/red dye) } & \multicolumn{4}{|c|}{ Slide 2 (red/green dye) } \\
\hline VCAM-1 & 7.016 & 4.589 & 0.765 & 1.187 & 0.114 & 0.17 & 1.279 & 0.891 \\
\hline LAMA3 & 7.283 & 5.181 & 1.279 & 1.89 & 0.161 & 0.168 & 1.115 & 2.774 \\
\hline LAMC2 & 2.259 & 1.139 & 0.541 & 0.975 & 0.293 & 0.431 & 1.147 & 0.533 \\
\hline OLR1 & 6.024 & 4.916 & 0.776 & 1.229 & 0.15 & 0.252 & 1.34 & 1.44 \\
\hline CXCL1 & 13.85 & 11.39 & 0.419 & 0.667 & 0.118 & 0.0403 & 0.773 & 0.594 \\
\hline CXCL2 & 6.797 & 4.963 & 1.09 & 0.979 & 0.163 & 0.144 & 1.184 & 1.256 \\
\hline CXCL3 & 6.182 & 5.154 & 0.991 & 1.034 & 0.207 & 0.14 & 1.243 & 1.301 \\
\hline CXCL5 & 3.983 & 2.603 & 1.099 & 0.516 & 0.303 & 0.201 & 1.466 & 0.716 \\
\hline CXCL10 & 5.954 & 2.897 & 0.534 & $\mathrm{ND}^{2}$ & 0.211 & 0.395 & 2.19 & 1.588 \\
\hline CX3CL1 & 3.396 & 2.97 & 0.88 & 1.078 & 0.334 & 0.342 & 0.985 & 1.445 \\
\hline CXCR4 & 8.039 & 3.535 & 0.542 & 0.943 & 0.0737 & 0.124 & 1.005 & 0.537 \\
\hline TNFAP2 & 7.09 & 4.561 & 0.695 & 1.558 & 0.151 & 0.267 & 1.222 & 0.809 \\
\hline
\end{tabular}

${ }^{1}$ VCAM-1 = vascular cell adhesion molecule-1; ICAM-1 = intercellular adhesion molecule-1; LAMA3 = laminin, $\alpha 3$; LAMC2 = laminin, $\gamma 2$; OLR1 = oxidized low-density lipoprotein receptor 1 ; CCL = chemokine ligands; CXCR = chemokine receptors; LTB = leukotriene B; TNF- $\alpha$ $=$ tumor necrosis factor- $\alpha$.

${ }^{2} \mathrm{ND}=$ not detected.

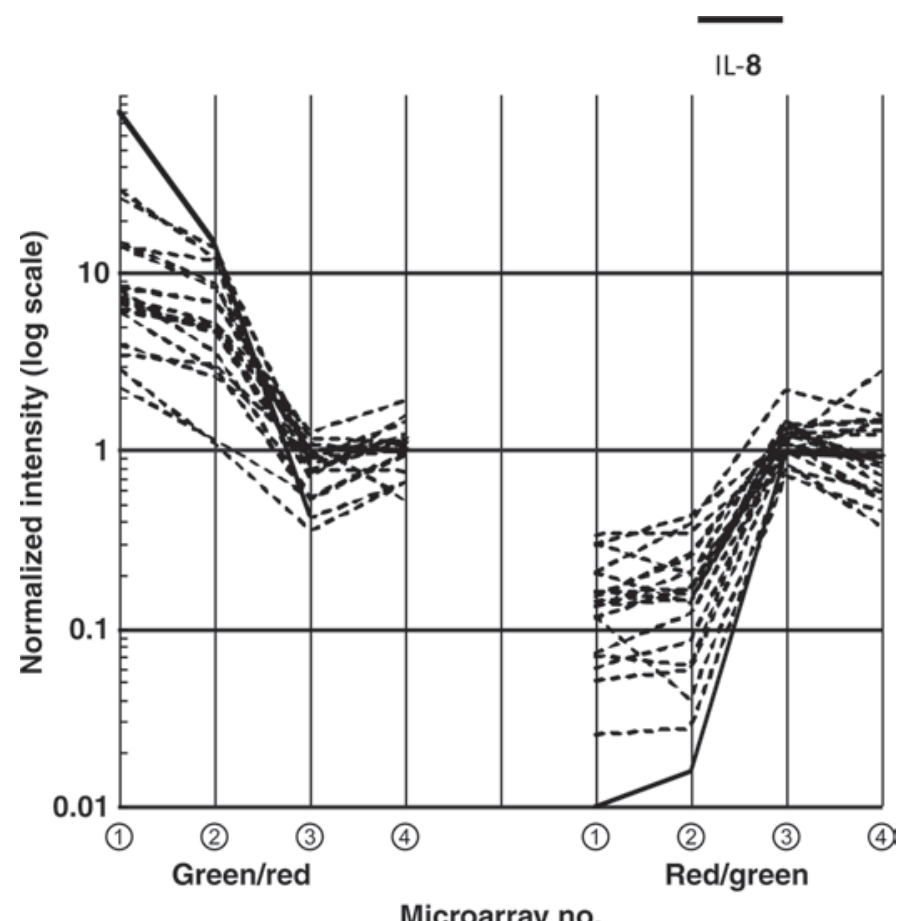

Microarray no.

Figure 2. Normalized intensities [cyanine (Cy)5/Cy3] of genes. The genes that have the same profile as IL- 8 in 4 microarrays were selected using GeneSpring GX7.3 software (Agilent Technologies Inc., Santa Clara, CA). Each line represents a gene. A solid line represents IL-8 and dotted lines represent other genes. The left graph shows IL8-like genes in slide 1 and the right graph shows IL-8-like genes in slide 2 . expression in infected cells in the presence and absence of BF-1. Infection with H. pylori induces gastric inflammatory responses. Comprehensive microarray analyses of human gastric cells have shown that various genes are upregulated in H. pylori-infected gastric cells. We confirmed these results, demonstrating by ELISA that IL-8 expression is suppressed by BF-1 pretreatment in infection models with $3 \mathrm{H}$. pylori strains. Microarray and real-time PCR data also support these results. The real-time PCR experiment demonstrated that IL- 8 expression is activated up to 49 times after $H$. pylori infection, and preincubation of BF-1 suppresses this effect by $33 \%$. Interleukin- 8 has been specifically implicated in the pathogenesis of $H$. pylori. Although the sample combination designs of the microarrays described here are complicated, this degree of complexity was necessary to identify those genes that, like IL-8, exhibit induction profiles that are suppressed by pre-incubation with BF1. These experiments identified many other genes (see Table 2) with profiles similar to that of IL-8, including genes of the C-C (RANTES, LARC), C-X-C (Gro- $\alpha, \beta$, $\gamma$, ENA-78, IL-8), C-X3-C (Fractalkine) motif chemokines, chemokine receptor (CXCR4/fusin), FGF18, interleukin (IL-23A), TNF superfamily proteins (Rink and Kirchner, 1996), matrix metallopeptidases, and cell adhesion molecules (ICAM-1, VCAM-1, Laminin). Interleukin- 8 and Gro- $\alpha$ preferentially recruit neutrophils, whereas RANTES primarily attract lymphocytes and monocytes (Baggiolini, 1998). Increased endothe- 
Table 4. List of genes induced by Helicobacter pylori and suppressed by Bifidobacterium bifidum BF-1

\begin{tabular}{|c|c|c|c|}
\hline Gene name ${ }^{1}$ & $\begin{array}{c}\text { Normalized } \\
\text { expression }\end{array}$ & $\begin{array}{l}\text { Relative } \\
\text { fold }^{2}\end{array}$ & $\begin{array}{l}\text { GenBank } \\
\text { accession no. }\end{array}$ \\
\hline VCAM-1 & 7.0 & 0.65 & NM_001078 \\
\hline ICAM-1 & 14.1 & 0.58 & NM_000201 \\
\hline LAMA3 & 5.8 & 0.46 & NM_198129 \\
\hline LAMC2 & 2.3 & 0.50 & NM_005562 \\
\hline OLR1 & 6.0 & 0.82 & NM_002543 \\
\hline CCL5 & 8.2 & 0.83 & NM_002985 \\
\hline CCL20 & 26.1 & 0.52 & NM_004591 \\
\hline CXCL1 & 13.9 & 0.82 & NM_001511 \\
\hline CXCL2 & 6.8 & 0.73 & NM_002089 \\
\hline CXCL3 & 16.4 & 0.54 & NM_002090 \\
\hline CXCL5 & 4.0 & 0.65 & NM_002994 \\
\hline CXCL10 & 6.0 & 0.49 & NM_001565 \\
\hline CX3CL1 & 5.5 & 0.46 & NM_002996 \\
\hline CXCR4 & 8.0 & 0.44 & NM_001008540 \\
\hline IL-8 & 80.4 & 0.18 & NM_000584 \\
\hline IL-23A & 2.9 & 0.37 & NM_016584 \\
\hline FGF18 & 14.7 & 0.58 & NM_003862 \\
\hline LTB & 8.3 & 0.80 & NM_002341 \\
\hline TNF- $\alpha$ & 28.6 & 0.41 & NM_000594 \\
\hline TNFAIP2 & 7.1 & 0.64 & NM_006291 \\
\hline TNFAIP3 & 6.2 & 0.67 & NM_006290 \\
\hline TNFRSF1B & 2.1 & 0.77 & NM_001066 \\
\hline TNFSF10B & 2.8 & 0.66 & NM_003842 \\
\hline TRAF1 & 5.5 & 0.51 & NM_005658 \\
\hline MMP1 & 2.8 & 0.35 & NM_002421 \\
\hline MMP9 & 4.1 & 0.68 & NM_004994 \\
\hline NFKBIA & 6.0 & 0.68 & NM_020529 \\
\hline
\end{tabular}

${ }^{1}$ VCAM-1 = vascular cell adhesion molecule-1; ICAM-1 = intercellular adhesion molecule-1; LAMA3 = laminin, $\alpha 3$; LAMC2 = laminin, $\gamma 2$; OLR1 = oxidized low-density lipoprotein receptor 1 ; CCL $=$ chemokine ligands; $\mathrm{CXCR}=$ chemokine receptor; LTB $=$ leukotriene $\mathrm{B}$; TNF- $\alpha=$ tumor necrosis factor- $\alpha$; TNFAIP $=$ TNF- $\alpha-$ induced protein; TNFRSF $=$ TNF receptor superfamily; TRAF $=$ TNF receptor-associated factor; ITGB $8=$ integrin beta-8; NFKBIA = nuclear factor of kappa light polypeptide gene enhancer in B-cells inhibitor, alpha; $\mathrm{MMP}=$ matrix metallopeptidases.

${ }^{2}$ Relative fold is a ratio of normalized expression of array 1 and array 2 (array 2/array 1 ).

lial cell expression of the adhesion molecules VCAM-1 and ICAM-1 supports the recruitment of leukocytes to the site of inflammation and perpetuates the ongoing inflammatory process (Kelly et al., 2007). These genes are known to have close interactions with each other. Although the mechanism of H. pylori-induced inflammation is not yet fully understood, the translation factor NF- $\kappa \mathrm{B}$ plays a key role in gene regulation during the inflammatory response. In endothelial cells, NF- $\kappa$ B regulates the expression of VCAM- 1 and ICAM1 , as well as that of many cytokines, including IL-8, Gro- $\alpha$, RANTES, and TNF- $\alpha$ (Innocenti et al., 2002). It is noteworthy that the $H$. pylori-induced and BF1-suppressed genes overlap with the genes regulated

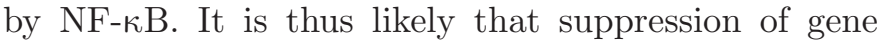
expression by $\mathrm{BF}-1$ is the result of $\mathrm{BF}-1$ interference with the NF- $\mathrm{BB}$ regulatory pathways.

The mechanism by which BF-1 affects gene expression is unknown. One possible explanation is that a direct competition between $H$. pylori and BF-1 occurs on the cell surface. To eliminate the effect of direct bacteria-to-bacteria contact inhibition, the cells in our experiments were washed with medium 3 times. Bifidobacteria have strong adherent properties, so the possibility that BF-1 sticks to the surface of the cells cannot be excluded, but the effects of lactic acid, acetic acid, or $\mathrm{pH}$ variation produced by $\mathrm{BF}-1$ were eliminated by the wash step.

Another possibility is that BF-1 inhibits the intracellular pathogenic function of H. pylori. Helicobacter pylori induces NF- $\kappa \mathrm{B}$ activation via intracellular signaling pathways in toll-like-receptor dependent and independent pathways. Toll-like receptor (TLR) 2 and TLR5 have been shown to recognize $H$. pylori and to initiate signaling pathways that result in enhanced activation of NF-kB (Smith et al., 2003; Torok et al., 2005). In our study, no variation in TLR gene expression was detected. In epithelial cells, the major roles of TLR are ambiguous (Ferrero, 2005; Hirata, et al., 2006). Helicobacter pylori can direct signaling in gastric epithelial cells through cytotoxin-associated gene A (CagA) to activate $\mathrm{NF}-\kappa \mathrm{B}$, leading to the release of chemokines 
(a)

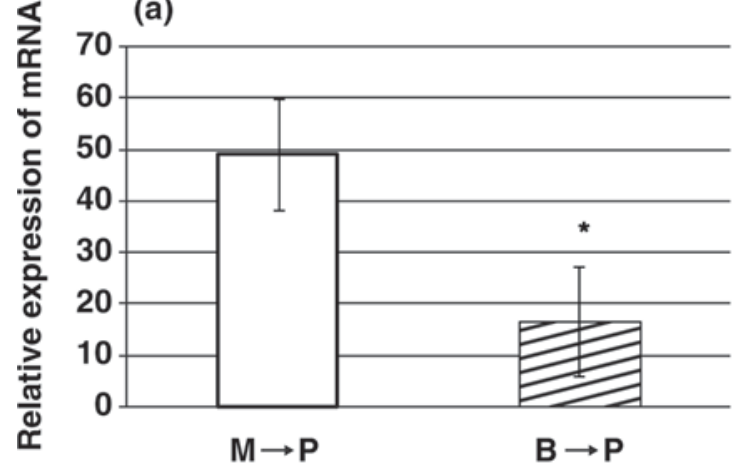

(b)

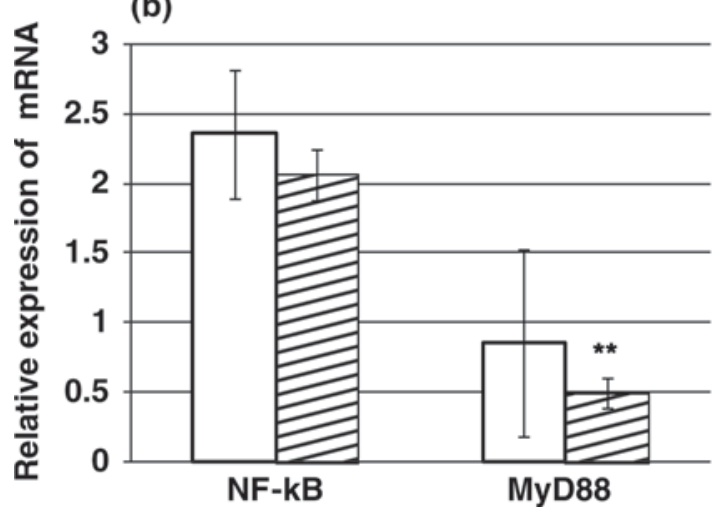

Figure 3. (a) Relative expression rate of IL- 8 mRNA induced by Helicobacter pylori quantified by real-time PCR; (b) relative expression rate of nuclear factor- $\kappa \mathrm{B}(\mathrm{NF}-\kappa \mathrm{B})$ and myeloid differentiation primary response gene-88 (MyD88) mRNA induced by H. pylori. Data are the means \pm standard deviations of the means $(\mathrm{n}=3)$. ${ }^{*} P<$ $0.04,{ }^{*} P<0.03$ for $H$. pylori-induced genes not preincubated versus preincubated with BF-1. $\mathrm{M}=$ media; $\mathrm{B}=\mathrm{BF}-1 ; \mathrm{P}=H$. pylori. Open bar $(\mathrm{M} \rightarrow \mathrm{P})$ represents the sample without preincubation. Hatched bar $(\mathrm{B} \rightarrow \mathrm{P})$ represents the sample preincubated with BF-1.

such as IL-8. Although the interaction of CagA and BF-1 has not yet been studied, our preliminary data show that BF-1 affects CagA production.

The other possibility is that BF-1 directly interacts with and suppresses NF- $\mathrm{BB}$, improving gastric symptoms by suppressing the inflammatory pathway, which includes IL-8. The results of the real-time PCR experiment suggest that BF-1 does not directly suppress $\mathrm{NF}-\kappa \mathrm{B}$ transcription; however, even a slight variation may lead to significant effects because NF- $\kappa \mathrm{B}$ is a key regulatory gene.

One final possibility is that preactivation of $\mathrm{BF}-1$ may suppress the drastic activation of gene expression by $H$. pylori. No upregulation or downregulation more than 2-fold of NF- $\mathrm{kB}$ or other inflammatory cytokines was detected in cells incubated with BF-1 alone, indicating that BF-1 does not induce inflammatory events in epithelial cells. It remains possible, however, that undetectable preceding stimulation by $\mathrm{BF}-1$ may make regulatory genes insensitive to the following stimulation by $H$. pylori.

Wen et al. (2004) reported the cDNA array analysis in gastric tissue obtained from biopsy specimens of $H$. pylori-infected patients. Although their results differ somewhat from those reported here, these differences likely reflect variability between cultured cells versus in situ tissues. Both reports list inflammatory genes, such as Gro- $\alpha, \beta, \gamma$, ENA-78, VCAM-1, and ICAM-1, that are upregulated by $H$. pylori infection. Thus, these results allow us to speculate that the BF-1 suppression mechanism might work in the human stomach. Normalization of the numbers of infiltrating neutrophils and expression of IL-8 were achieved by eradication of $H$. pylori (Ando et al., 1998). Therefore, the suppression of IL-8 and other inflammatory genes by BF-1 may contribute to the improvement of gastric function.

The identity of the BF-1 factor responsible for its suppressing effects is not yet known. Previous studies have shown that TNF- $\alpha$-induced IL- 8 expression was inhibited by $B$. bifidum-conditioned medium and its DNA, but not by heat-treated bacteria in HT-29 cells (Imaoka et al., 2008). Bifidobacterium bifidum inhibits LPS-induced NF- $\kappa \mathrm{B}$ activation in HT-29 intestinal epithelial cells (Riedel et al., 2006). Polysaccharide fractions of B. bifidum, composed primarily of rhamnose, have an anti-ulcer effect in humans (Nagaoka et al., 1994). Taken together, polysaccharide fractions seem to be an important factor in cellular interactions; however, for many probiotics, it is known that the whole cell body is required to induce a strong immune response in cells (Sekine et al., 1985). The reinforcement of immunity caused by probiotics may also contribute to the suppression of $H$. pylori in vivo. The in vivo analysis of BF-1 effects on gene expression should be investigated in future studies.

\section{ACKNOWLEDGMENTS}

We are grateful to Haruji Sawada of our institute for his encouragement and helpful advices. We also thank Naomi Harima-Mizusawa, Atsushi Gomi, and Akira Iwata of our laboratory for technical help and discussion.

\section{REFERENCES}

Ando, T., K. Kusugami, M. Ohsuga, K. Ina, M. Shinoda, T. Konagaya, T. Sakai, A. Imada, N. Kasuga, T. Nada, S. Ichiyama, and M. J. Blaser. 1998. Differential normalization of mucosal Interleukin-8 and Interleukin-6 activity after Helicobacter pylori eradication. Infect. Immun. 66:4742-4747.

Baggiolini, M. 1998. Chemokines and leukocyte traffic. Nature 392:565-568.

Bernet, M.-F., D. Brassart, J.-R. Neeser, and A. L. Servin. 1993. Adhesion of human Bifidobacterial strains to cultured human intestinal 
epithelial cells and inhibition of enteropathogen-cell interactions. Appl. Environ. Microbiol. 59:4121-4128.

Boonyaritichaikij, S., K. Kuwabara, J. Nagano, K. Kobayashi, and Y. Koga. 2009. Long-term administration of probiotics to asymptomatic pre-school children for either the eradication or the prevention of Helicobacter pylori infection. Helicobacter 14:202-207.

Crabtree, J. E., J. I. Wyatt, L. K. Trejdosiewicz, P. Peichl, P. H. Nichols, N. Ramsay, J. N. Primrose, and I. J. Lindley. 1994. Interleukin-8 expression in Helicobacter pylori infected, normal, and neoplastic gastroduodenal mucosa. J. Clin. Pathol. 47:61-66.

Ferrero, R. L. 2005. Innate immune recognition of the extracellular mucosal pathogen, Helicobacter pylori. Mol. Immunol. 42:879-885.

Gueimonde, M., L. Noriega, A. Margolles, C. G. Reyes-Gavilan, and S. Salminen. 2005. Ability of Bifidobacterium strains with acquired resistance to bile to adhere to human intestinal mucus. Int. J. Food Microbiol. 101:341-346.

Guglielmetti, S., I. Tamagnini, D. Mora, M. Minuzzo, A. Scarafoni, S. Arioli, J. Hellman, M. Karp, and C. Parini. 2008. Implication of an outer surface lipoprotein in adhesion of Bifidobacterium bifidum to Caco-2 cells. Appl. Environ. Microbiol. 74:4695-4702.

Hirata, Y., T. Ohmae, W. Shibata, S. Maeda, K. Ogura, H. Yoshida, T. Kawabe, and M. Omata. 2006. MyD88 and TNF receptor-associated factor 6 are critical signal transducers in Helicobacter pyloriinfected human epithelial cells. J. Immunol. 176:3796-3803.

Imaoka, A., T. Shima, K. Kato, S. Mizuno, T. Uehara, S. Matumoto, H. Setoyama, T. Hara, and Y. Umesaki. 2008. Anti-inflammatory activity of probiotic Bifidobacterium: enhancement of IL-10 production in peripheral blood mononuclear cells from ulcerative colitis patients and inhibition of IL-8 secretion in HT-29 cells. World J. Gastroenterol. 14:2511-2516.

Innocenti, M., A.-C. Thoreson, R. L. Ferrero, E. Strömberg, I. Bölin, L. Eriksson, A.-M. Svennerholm, and M. Quiding-Järbrink. 2002. Helicobacter pylori-induced activation of human endothelial cells. Infect. Immun. 70:4581-4590.

Kelly, M., J. M. Hwang, and P. Kubes. 2007. Modulating leukocyte recruitment in inflammation. J. Allergy Clin. Immunol. 120:3-10.

Maeda, S., M. Akanuma, Y. Mitsuno, Y. Hirata, K. Ogawa, H. Yoshida, Y. Shiratori, and M. Omata. 2001. Distinct mechanism of Helicobacter pylori-mediated NF- $\mathrm{KB}$ activation between gastric cancer cells and monocytic cells. J. Biol. Chem. 276:44856-44864.

Miki, K., Y. Urita, F. Ishikawa, T. Iino, H. Shibahara-Sone, R. Akahoshi, S. Mizusawa, A. Nose, D. Nozaki, K. Hirano, C. Nonaka, and T. Yokokura. 2007. Effect of Bifidobacterium bifidum fermented milk on Helicobacter pylori and serum pepsinogen levels in humans. J. Dairy Sci. 90:2630-2640.

Morris, A., and G. Nicholson. 1987. Infection of Campylobacter pylori causes gastritis and raised fasting gastric $\mathrm{pH}$. Am. J. Gastroenterol. 82:192-199.

Myllyluoma, E., A.-M. Ahonen, R. Korpela, H. Vapaatalo, and E. Kankuri. 2008. Effects of multispecies probiotic combination on Helicobacter pylori infection in vitro. Clin. Vaccine Immunol. 15:1472-1482.

Nagaoka, M., S. Hashimoto, T. Watanabe, T. Yokokura, and Y. Mori. 1994. Anti-ulcer effects of lactic acid bacteria and their cell wall polysaccharides. Biol. Pharm. Bull. 17:1012-1017.

Nagaoka, M., Y. Yamamoto, T. Suzuki, M. Hirano, H. Shibata, I. Kimura-Takagi, R. Aiyama, S. Hashimoto, S. Ueyama, and T. Yokokura. 2003. Effect of Fucoidan from Cladosiphon okamuranus and Bifidobacterium bifidum strain Yakult on the eradication of Helicobacter pylori. J. Japan. Soc. Clin. Stud.Intest. Microflora 4:57-61. (in Japanese)

Nozue, M., M. Nishida, T. Todoroki, and Y. Iwasaki. 1991. Establishment and characterization of a human scirrhus type gastric cancer cell line, GCIY, producing CA19-9. Hum. Cell 4:71-75. (in Japanese)

Lesbros-Pantoflickova, D., I. C. Theulaz, and A. L. Blum. 2007. Helicobacter pylori and Probiotics. J. Nutr. 137:812S-818S.

Picard, C., J. Fioramonti, A. Francois, T. Robinson, F. Neant, and C. Matuchansky. 2005. Review article: bifidobacteria as probiotic
agents-Physiological effects and clinical benefits. Aliment. Pharmacol. Ther. 22:495-512.

Riedel, C. U., F. Foata, D. Philippe, O. Adolfsson, B. J. Eikmanns, and S. Blum. 2006. Anti-inflammatory effects of bifidobacteria by inhibition of LPS-induced NF- $\kappa \mathrm{B}$ activation. World J. Gastroenterol. 12:3729-3735.

Rink, L., and H. Kirchner. 1996. Recent progress in the tumor necrosis factor- $\alpha$ field. Int. Arch. Allergy Immunol. 111:199-209.

Sachdeva, A., and J. Nagpal. 2009. Effect of fermented milk-based probiotic preparations on Helicobacter pylori eradication: A systematic review and meta-analysis of randomized-controlled trials. Eur. J. Gastroenterol. Hepatol. 21:45-53.

Sakamoto, I., M. Igarashi, K. Kimura, A. Takagi, T. Miwa, and Y. Koga. 2001. Suppressive effect of Lactobacillus gasseri OLL2716 (LG21) on Helicobacter pylori infection in humans. J. Antimicrob. Chemother. 47:709-710.

Sekine, K., T. Toida, M. Saito, M. Kuboyama, M. Kawashima, and Y. Hashimoto. 1985. A new morphologically characterized cell wall preparation (whole peptidoglycan) from Bifidobacterium infantis with a higher efficacy on the regression of an established tumor in mice. Cancer Res. 45:1300-1307.

Selgrad, M., A. Kandulski, and P. Malfertheiner. 2009. Helicobacter pylori: Diagnosis and treatment. Curr. Opin. Gastroenterol. 25:549-556.

Sharma, S. A., M. K. R. Tummuru, M. J. Blaser, and D. K. Lawrence. 1998. Activation of IL-8 gene expression by Helicobacter pylori is regulated by transcription factor nuclear factor- $\kappa \mathrm{B}$ in gastric epithelial cells. J. Immunol. 160:2401-2407.

Sheu, B.-S., H.-C. Cheng, A.-W. Kao, S.-T. Wang, Y.-J. Yang, H.-B. Yang, and J.-J. Wu. 2006. Pretreatment with Lactobacillus- and Bifidobacterium-containing yogurt can improve the efficacy of quadruple therapy in eradicating residual Helicobacter pylori infection after failed triple therapy. Am. J. Clin. Nutr. 83:864-869.

Shimakawa, Y., S. Matsubara, N. Yuki, M. Ikeda, and F. Ishikawa. 2003. Evaluation of Bifidobacterium breve strain Yakult-fermented soymilk as a probiotic food. Int. J. Food Microbiol. 81:131-136.

Smith, M. F. Jr., A. Mitchell, G. Li, S. Dings, A. M. Fitzmaurice, K. Ryan, S. Crowe, and J. B. Goldberg. 2003. Toll-like receptor (TLR) 2 and TLR5, but not TLR4, are required for Helicobacter pylori-induced NF- $\kappa \mathrm{B}$ activation and chemokine expression by epithelial cells. J. Biol. Chem. 278:32552-32560.

Torok, A. M., A. H. Bouton, and J. B. Goldberg. 2005. Helicobacter pylori induces Interleukin-8 secretion by Toll-like receptor 2 - and Toll-like receptor 5 -dependent and -independent pathways. Infect. Immun. 73:1523-1531.

Uemura, N., T. Mukai, S. Okamoto, S. Yamaguchi, H. Mashiba, K. Taniyama, N. Sasaki, K. Haruma, K. Sumii, and G. Kajiyama. 1997. Effect of Helicobacter pylori eradication on subsequent development of cancer after endoscopic resection of early gastric cancer. Cancer Epidemiol. Biomarkers Prev. 6:639-642.

Wang, K. Y., S. N. Li, C. S. Liu, D. S. Perng, Y. C. Su, D. C. Wu, C. M. Jan, C. H. Lai, T. N. Wang, and W. M. Wang. 2004. Effects of ingesting Lactobacillus- and Bifidobacterium-containing yogurt in subjects with colonized Helicobacter pylori. Am. J. Clin. Nutr. 80:737-741.

Wen, S., C. P. Felley, H. Bouzourene, M. Reimers, P. Michetti, and Q. Pan-Hammarström. 2004. Inflammatory gene profiles in gastric mucosa during Helicobacter pylori infection in humans. J. Immunol. 172:2595-2606.

Worona-Dibner, L. 2009. Randomized, double-blind, placebo-controlled trial: Effect of Lactobacillus GG supplementation on Helicobacter pylori eradication rates and side effects during treatment in children. Rev. Gastroenterol. Mex. 74:142-143. (in Spanish).

Yamaoka, Y., M. Kita, T. Kodama, N. Sawai, T. Tanahashi, K. Kashima, and J. Imanishi. 1998. Chemokines in the gastric mucosa in Helicobacter pylori infection. Gut 42:609-617. 